\title{
EUROPEIZACJA DZIEDZICTWA. O MORALNYM ZAANGAŻOWANIU PEWNEGO POJĘCIA ${ }^{1}$
}

\author{
Abstract \\ EUROPEANIZATION OF HERITAGE. ABOUT THE MORAL INVOLVEMENT \\ OF A CERTAIN NOTION
}

This article attempts to describe the reciprocal relationship between the stages of European integration, with its acceleration and crises since the 1990's, and the manner of building transnational historical narratives and exploiting the notion of European heritage. The authors show the cultural dimension of Europeanization which, by enriching something that was originally of a purely political and institutional nature, is seen in the subsequent scientific and political paradigms of the construction of a common European past and culture.

SŁOWA KLUCZE: integracja, europeizacja, dziedzictwo europejskie, kultura, przeszłość

KEY WORDS: integration, europeanization, european heritage, culture, the past

Pojęciem ostrym nie jest ani europeizacja, ani dziedzictwo. Tym bardziej europeizacja dziedzictwa musi budzić jeszcze więcej pytań i wątpliwości, które odnosić się mogą zarówno do synergicznego połączenia obu tych pojęć, jak i do każdego z nich osobno. Nieklarowność znamionuje więc i dziedzictwo, i europeizację, i ostatecznie również europeizację dziedzictwa. W konsekwencji pytać można zasadnie, czy „ponowoczesna płynność” granic konceptualnych oraz brak jasnych i utrwalonych rygorów stosowania tych pojęć do opisu zjawisk kultury, polityki i ekonomii

${ }^{1}$ Projekt został sfinansowany ze środków Narodowego Centrum Nauki przyznanych na podstawie decyzji numer DEC-2013/08/M/HS6/0004. Niektóre z przedstawionych tu idei można również znaleźć w: K. Kowalski, B. Törnquist-Plewa, Heritage and Memory in a Changing Europe. Introductory Remarks [w:] K. Kowalski, B. Törnquist-Plewa (red.), The Europeanization of Heritage and Memories in Poland and Sweden, Kraków 2016, s. 15-31. 
przesądza - lub też już przesądziła - o ich sukcesie? Czy też owa mglistość prowadzi do klęski wyrażającej się w niszowym zastosowaniu i mocno ograniczonym kręgu tych, którzy dziedzictwo dyskursywnie powołują do życia, i tych, którzy je interpretują z, przykładowo, europejskiej perspektywy?

Dziś, w drugiej dekadzie XXI wieku widoczny jest sukces odnoszony przez dziedzictwo, które - często wynosząc na powierzchnię społecznego przeżywania treści dotąd pomijane i dając głos niesłyszanym - jest wszechobecne. Ponadto, czego nie należy pomijać, oddaje ono przeszłość w ręce nowych koryfeuszy generujących coraz to nowe interpretacje przeszłości i legitymizujących coraz to nowe cele polityki kulturalnej regionów, miast, narodów, Europy. Pozycja dziedzictwa w obszarze społecznego konstruowania i przeżywania przeszłości wydaje się już ugruntowana, ale cele, które stawia się przed dziedzictwem, wyraźnie ulegają transformacji.

Artykuł niniejszy podejmuje próbę opisania wpływu integracji europejskiej (z jej przyspieszeniami i kryzysami) od lat dziewięćdziesiątych XX wieku na sposoby definicji dziedzictwa i budowania ponadnarodowych narracji oraz ich ewolucji. To opowieść o swoistej symetrii, którą można tropić między stanem integracji (lub dezintegracji) UE a akademickimi paradygmatami (lub nawet modami) konstruowania wspólnych ponadnarodowych narracji i dziedzictwa europejskiego.

\section{Integracja polityczna a teorie europeizacji}

Choć definicji europeizacji jest wiele, to jednak najczęściej ujmuje się ją jako wielowymiarowy proces, któremu ulegają państwa europejskie, ich instytucje, organy i polityki pod wpływem współpracy z Unią Europejską, negocjacji akcesyjnych i członkostwa w UE². Traktat z Maastricht (1992) był swoistą cezurą, od której refleksja nad instytucjonalnymi konsekwencjami, które można obserwować w państwach członkowskich, była/jest często podejmowana. Dwa lata po podpisaniu Traktatu o Unii Europejskej Robert Ladrech zwracał uwagę, że europeizacja jest procesem, którego rezultat ma wyraźnie kumulacyjny charakter i że pod jej wpływem zmienia się kierunek oraz kształt polityk państw członkowskich. Rozległość i głębokość tej ewolucji zależy - według tego autora - od stopnia, w jakim pryncypia polityczne i gospodarcze UE są inkorporowane do logiki organizacyjnej państw członkowskich prowadzących swoje polityki wewnętrzne i zewnętrzne ${ }^{3}$. Podobny, jednowektorowy charakter relacji podkreślała kilka lat później Tanja Börzel (1999),

2 Zob. P. Graziano, M.P. Vink, Europeanization: Concept, Theory, and Methods [w:] S. Bulmer, Ch. Lesquene (red.), The Member States of the European Union, New York 2005, s. 31-54.

${ }^{3}$ R. Ladrech, Europeanization of Domestic Politics and Institutions: The Case of France, „Journal of Common Market Studies” 1994, vol. 32:1, s. 17. Ladrech, rozwijając tę myśl, zaproponował wiele lat później (2010) definicję europeizacji, którą przedstawił ,jako zmianę dokonującą się w państwie członkowskim, którą logicznie motywuje powiązanie z polityką UE lub z unijnym procesem decyzyjnym". W konsekwencji badania nad europeizacją powinny w jego rozumieniu przede wszystkim koncentrować się na ustaleniu związku przyczynowego-skutkowego między 
definiując europeizację jako „proces, poprzez który obszary polityki wewnętrznej w coraz większym stopniu podlegają europejskiemu procesowi decyzyjnemu"4.

W czasie, gdy negocjacje akcesyjne Polski i innych państw Europy Środkowej i Wschodniej dobiegały końca (2002), głęboko instytucjonalny i odśrodkowy charakter europeizacji podkreślali Maria Green Cowles, James A. Caporaso i Thomas Risse-Kappen (2001), którzy wiązali ją z ,pojawieniem się i rozwojem na poziomie europejskim odrębnych struktur zarządzania, a mianowicie instytucji politycznych, prawnych i społecznych, które wiążą się z rozwiązywaniem politycznych problemów i formalizują interakcje między podmiotami" europejskiej sceny politycznej. Autorzy dodawali ponadto, że europeizacja wiąże się z powstaniem i rozkwitem politycznych sieci specjalizujących się w tworzeniu reguł polityki europejskiej5. W tym samym czasie (2001) podobnie pisała Adrienne Héritier. Według niej, europeizacja jest „procesem oddziaływania wynikającym z europejskich decyzji i wpływającym na politykę państw członkowskich oraz ich struktury polityczne i administracyjne”. Ów proces obejmuje same decyzje podejmowane przez instytucje europejskie, procesy, które owe decyzje generują oraz ostatecznie ich wpływ na politykę krajową państw członkowskich, ich procesy decyzyjne i struktury instytucjonalne ${ }^{6}$. Warto podkreślić, że definicje europeizacji proponowane w tym okresie nie uwzględniały kultury. Rozumiano ją jako proces głęboko polityczny oraz instytucjonalny.

Często przywoływana jest definicja Claudio M. Radaellego, który - w roku zakończenia negocjacji Polski z UE i referendum akcesyjnego (2003) - nieco inaczej rozkładał akcenty i definiował europeizację jako

[...] proces a) konstruowania, b) dyfuzji i c) instytucjonalizacji formalnych i nieformalnych zasad, procedur, paradygmatów polityki, stylów, „sposobów działania”, wspólnych przekonań i norm, które po raz pierwszy zostały zdefiniowane i wyrażone w procesie tworzenia UE, a następnie zostały włączone do logiki krajowych dyskursów, tożsamości, struktur politycznych i polityk publicznych? ${ }^{7}$.

Siła definicji Radaellego wynika z faktu, że, poza poniekąd niewątpliwym wymiarem instytucjonalnym, zwraca ona uwagę na kulturowy aspekt dokonującej się europeizacji. W duchu tego spojrzenia ów proces diagnozować można na podstawie symptomów przyjmowania europejskich przekonań i norm oraz podzielania wspólnych, europejskich wartości. Innymi słowy, autor wychodzi poza czysto

członkostwem w UE a zmianami w kraju członkowskim (R. Ladrech, Europeanization and National Politics, Basingstoke 2010, s. 2).

${ }^{4}$ T. Börzel, Towards Convergence in Europe? Institutional Adaptation to Europeanization in Germany and Spain, „Journal of Common Market Studies” 1999, vol. 39:4, s. 574.

${ }_{5}$ T. Risse, M.G. Cowles, J. Caporaso, Europeanization and Domestic Change: Introduction [w:] M.G. Cowles, J. Caporaso, T. Risse (red.), Transforming Europe: Europeanization and Domestic Change, Ithaca, NY, 2001, s. 3.

${ }^{6}$ A. Héritier et. al., Differential Europe. The European Union Impact on national Policymaking, Lanham, MD, 2001, s. 574.

7 C. Radaelli, The Europeanization of Public Policy [w:] K. Featherstone, C.M. Radaelli (red.), The Politics of Europeanization, Oxford 2003, s. 30. 
instytucjonalne i polityczne spojrzenie oraz zauważa konsekwencje integracji w narodowych kulturach i społeczeństwach, w logice instytucji/administracji, w ich działaniach, dyskursie oraz - ostatecznie - w jednostkowej i zbiorowej tożsamości. Definicja Radaellego jest swoistym signum temporis. Widać w niej bowiem otwarcie na olbrzymi i wewnętrznie zróżnicowany przedmiot badań i refleksji, który tę definicję przekracza i równocześnie jest jej logicznym rozwinięciem. Otóż ów przedmiot badań odnosi się - po pierwsze - do sposobu, w jaki Europa jest przeżywana w lokalnym kontekście; po drugie - nawiązuje do obrazów i emocji, na podstawie których budowana jest jej lokalna reprezentacja; oraz - po trzecie - wskazuje na tych, którzy owej implementacji dokonują w lokalnym kontekście, co czynią w nawiązaniu do wernakularnych celów i wartości. Innymi słowy, to przestrzeń refleksji nad wpływem procesu integracji politycznej na dyskursywne praktyki generujące obrazy Europy i sposoby jej interpretacji

$\mathrm{W}$ podobnym duchu, i wychodząc poza czysto instytucjonalne ramy europeizacji, Gerard Delanty wyrażał krytyczny pogląd (2005) wobec tych ujęć omawianego zjawiska, które łączyły je tylko z procesem integracji politycznej Unii Europejskiej, jej kolejnymi rozszerzeniami i ewoluującymi granicami UE. Twierdził, że błędem jest definiowanie europeizacji jako odrębnego procesu, który nie ma związku z procesami szerszymi niż te, które przebiegają na Starym Kontynencie. Akcentował opinię, że europeizację należy ujmować raczej w relacji do procesów globalizacyjnych i ich konsekwencji widocznych na lokalnym poziomie. Innymi słowy, w jego ujęciu Europa jawiła się - i nadal jawi - jako poziom pośredniczący między areną globalnych trendów a ich lokalnymi aplikacjami. $Z$ tego powodu konieczne było/jest uwzględnienie w badaniach nad Europą owych globalnych trendów widocznych w elektronicznych mediach, masowej turystyce, w kolejnych falach migracyjnych przelewających się przez cały świat $\mathrm{i}$ - ostatecznie - w globalnym rozprzestrzenianiu się idei kosmopolitycznej tożsamości, tak drogiej (w) Europie. Patch-workowy charakter europeizacji nie tyle wyróżnia dzisiejszą Europę, ile jest raczej właściwy współczesnemu światu9 . Innymi słowy, Europa, zachowując specyfikę i odrębność, równocześnie nie jest wolna od modernizacyjnych procesów przebiegających wszędzie poza jej granicami instytucjonalnymi, politycznymi, kulturowymi, religijnymi, społecznymi etc. Badać Europę i europeizację, to znaczy uwzględniać również inne, szersze konteksty.

Refleksja nad wpływem integracji europejskiej na interpretacje dziedzictwa, polityki historyczne i strategie komemoratywne w państwach członkowskich UE

8 Ten wątek europeizacji badali przykładowo: M. Convey, K.K. Patel (red.), Europeanization in the Twenties Century. Historical Approaches, Basingstoke, Hampshire, New York 2010; O. Calligaro, Negotiating Europe. EU promotion of Europeanness since the 1950s, New York 2013; K. Kowalski, B. Törnquist-Plewa (red.), The Europeanization of Heritage and Memories in Poland and Sweden, Kraków 2016; Sh. Macdonald, Difficult Heritage: negotiating the Nazi past in Nuremberg and beyond, New York 2009; Sh. Macdonald, Memorylands: heritage and identity in Europe today, London-New York 2013.

${ }^{9}$ G. Delanty, C. Rumford, Rethinking Europe: social theory and the implications of Europeanization, London-New York 2005, s. 18. Por. G. Delanty, The cosmopolitan imagination: the renewal of critical social theory, Cambridge 2009. 
uwzględnia więc często trendy, które poza Europę wykraczają. Jednak ten fakt nie prowadzi do zarzucenia specyfiki właściwej „europeizacji Europy”10 (na korzyść opozycji globalne-lokalne), ponieważ w obszarze refleksji nad procesami przebiegającymi na Starym Kontynencie niebagatelne są: natężenie, kierunek i jakość współpracy państw członkowskich wewnątrz UE, wpływ członkowstwa i europejskich instytucji lub - przynajmniej - zaawansowanie negocjacji akcesyjnych.

Wyrazić więc można opinię, że nie jest prostym zbiegiem okoliczności fakt, iż to w konkretnych momentach procesu integracyjnego podjęto pierwsze próby uwspólnotowienia reinterpretacji przeszłości (szczególnie po 2004), wygenerowano nowe sposoby opisywania przeszłości (patrz wszelkie inicjatywy dotyczące dziedzictwa europejskiego po roku 2004) oraz - co szczególnie interesujące - zastosowano konkretne pojęcie do opisu wspólnej, ponadnarodowej i międzynarodowej historii, tj. odwołano się do dziedzictwa europejskiego (od połowy lat dziewięćdziesiątych XX wieku). Trzeba jednak zauważyć, że obserwowana europeizacja - co podkreślamy nie jest ani jednokierunkowa, ani nieodwołalna. Dają się bowiem już odczuć korekty zeuropeizowanego sposobu budowania wspólnego, europejskiego imaginarium, które choć słabo jeszcze wykształcone, to i tak jest niejednokrotnie kwestionowane.

Europeizację zdefiniować można więc jako złożony, wielopoziomowy i wielokierunkowy proces o różnych dynamikach i zasięgach, który - po pierwsze - związany jest z polityczną presją wynikającą z akcesji do UE i ze zmianami, które owa akcesja wywołuje. Ma on wyraźnie wertykalny i dwukierunkowy charakter (top-down i bottom-up). Po drugie, europeizacja objawia się również transnarodowymi zmianami i horyzontalną dyfuzją idei, która jest konsekwencją codziennej aktywności jednostek i społeczeństw Europy i która wychodzi poza narodowe limes. Ostatecznie po trzecie - europeizację uchwycić można w procesie definiowania i redefiniowania tego, co „tu” i „teraz” uznać należy za „europejskie”. Ten subtelny (trzeci) wymiar europeizacji związany jest z tymi wszystkimi przedsięwzięciami, które mają uczynić Europejczyków bardziej świadomymi naszej europejskiej kultury, cywilizacji, przeszłości, dziedzictwa etc. ${ }^{11}$. To redefinicja tożsamości jednostek i wspólnot, która nie prowadzi jednak do zastąpienia tożsamości narodowych przez tożsamość europejską, ale do ich relatywizacji lub spojrzenia na nie z innej perspektywy niż narodowa.

Badanie europeizacji w odniesieniu do procesów konstruowania przeszłości, jej użycia i interpretacji wymaga uwzględnienia całej złożoności oddziaływań top-down i bottom-up oraz horyzontalnego (transnarodowego) rozchodzenia się idei. Każdy $\mathrm{z}$ tych wymiarów jest inicjowany przez innych aktorów życia społecznego. I tak, na poziomie państw europeizacja może prowadzić do budowania i akceptacji takich wizji przeszłości (prezentowanych np. w muzeach), które oznaczają rezygnację z narodowych, monolitycznych i etnocentrycznych punktów widzenia ${ }^{12}$. W tym wypadku

${ }^{10}$ Por. P. Mazurkiewicz, Europeizacja Europy: tożsamość kulturowa Europy w kontekście procesów integracji, Warszawa 2001.

${ }^{11}$ Por. C. Shore, Building Europe, London-New York 2000; M. Sassatelli, Becoming Europeans. Cultural Identity and Cultural Policies, Houndmills-Basingstoke-Hampshire 2009.

12 Przykładami zeuropeizowanych narracji muzealnych są stałe ekspozycje Europejskiego Centrum Solidarności (ECS) i Muzeum II Wojny Światowej w Gdańsku. Patrz: oficjalna strona 
europeizacja oznacza często rezygnację z godnościowej i narodowej wizji przeszłości, która podkreśla „naszą” krzywdę i ofiarę oraz „wasze” zobowiązanie do zadośćuczynienia. W nieeuropejskim ujęciu przeszłość podlega arytmetyce strat i filozofii rekompensaty, której ,jedni” żądają od „drugich”. Ponadto rozwinięciem etnocentrycznej wizji przeszłości jest czynienie „,rachunku za krzywdy w ojczyźnie”"13, który miesza przeszły wymiar materialny i symboliczny ze współczesnym wymiarem politycznym i ekonomicznym.

Europeizacja w przedstawianym tu rozumieniu oznacza odejście od mitologii narodowych, które określają odwiecznych wrogów i odwieczne krzywdy ${ }^{14}$. Zarzucone jest przekonanie o słuszności uniwersalnych praw rządzących przeszłością, teraźniejszością i przyszłością (np. „raz wróg, zawsze wróg”). Ponadto za zeuropeizowaną narrację o przeszłości należy uznać taką, która nie tyle opowiada wielką i wyjątkową historię narodu, ile poza nią uwzględnienia jeszcze szerszy kontekst, w który owa narracja narodowa jest wplatana (np. zjawiska podobnego typu albo wydarzenia w tym samym czasie, ale w innych częściach Europy lub świata ${ }^{15}$ ). Taki relatywizm i wszelkie jego formy dla narodowych i monolitycznych wizji przeszłości oznaczają osłabienie wyjątkowości i prymatu „naszego” losu. To powód zdecydowanego odrzucenia, na jaki narażona jest ze strony narodowych/monolitycznych wizji przeszłości każda narracja relatywizująca „naszą” narodową opowieść o „naszej” krzywdzie, „naszym” zwycięstwie, „naszym” poświęceniu etc. W tym rozumieniu opowieść zeuropeizowana może stać w kontrze do opowieści narodowej ${ }^{16}$.

Próby budowania ponadnarodowego imaginarium są podejmowane w kontekście dokonującej się politycznej integracji Europy, która w różnych momentach historii natrafia na opór, kryzysy i regres. Niezależnie od tej sinusoidalnej cykliczności Komisja Europejska, Parlament Europejski i Rada Europy podejmują wiele inicjatyw, które mają - raz - uczulać Europejczyków na wspólne cywilizacyjne korzenie,

ECS, http://www.ecs.gda.pl/ [odczyt: 1.08.2017] i oficjalna strona Muzeum II Wojny Światowej, http://www.muzeum1939.pl/ [odczyt: 1.08.2017]. Dyskusja wokół narracji muzealnej proponowanej przez Muzeum II Wojny Światowej może stanowić ilustrację do stawianych w tym artykule tez. Por. Ł. Piekarska-Duraj, Democratization as an Aspect of Heritage Europeanization. The Museum Triangle [w:] The Europeanization of Heritage and Memories..., s. 33-57.

${ }_{13}$ Nawiązanie do wiersza Władysława Broniewskiego Bagnet na broń (1939). Por. zapis wystąpienia Prezydenta RP Andrzeja Dudy (26 maja 2017 r.) na spotkaniu z Prezydentem Francji Emmanuelem Macron, https://www.tvn24.pl/wideo/z-anteny/sa-w-ojczyznie-rachunki-krzywd-duda-o-nowym-rozdziale-w-relacjach-polsko-francuskich,1628411.html?playlist_id=22892 [odczyt: 1.08.2017].

${ }_{14}$ Por. V. Tismaneanu, Wizje zbawienia. Demokracja, nacjonalizm i mit w postkomunistycznej Europie, Warszawa 2000.

15 Por. K. Kowalski, Euro-ethics. European Solidarity Centre in Gdańsk and the Narrative on the Polish Road to Freedom [w:] The Europeanization of Heritage and Memories..., s. 103-130. Omawiany w niniejszym artykule rodzaj narracji jest silnie wspierany przez współczesną historiografię, w ramach której od początku XXI wieku rozwija się kierunek zwany histoire croisée (M. Werner, B. Zimmermann, Beyond Comparison: Histoire Croisée and the Challenge of Reflexivity, „History and Theory", vol. 45, nr 1 (luty 2006), s. 30-50).

${ }_{16}$ Patrz ponownie: dyskusja wokół narracji muzealnej proponowanej przez ECS i Muzeum II Wojny Światowej. 
dwa - kształtować wizję wspólnej przeszłości (i wyciągać ją spod prymatu narodowej interpretacji) oraz - trzy - zmierzać do kształtowania/utrwalania tożsamości europejskiej ${ }^{17}$. Wizja wspólnej przeszłości ma więc służyć urzeczywistnieniu innej wizji, tej, która odnosi się do wspólnej przyszłości. W odgórnych procesach europeizacyjnych ten instytucjonalny wymiar jest bardzo istotny i budzi wiele kontrowersji, szczególnie wokół ich skuteczności. Zmierza on - ze zmiennym udziałem państw członkowskich i społeczności lokalnych - do definicji dziedzictwa europejskiego i identyfikacji europejskich miejsc pamięci ${ }^{18}$. Działania w tym obszarze dotyczą w szczególności tych materialnych i niematerialnych pozostałości przeszłości, które klasyfikują albo państwa członkowskie, albo instytucje europejskie (lub oba te poziomy razem) i uznają je ze wyraz wartości stricte europejskich. To ciągle dokonujący się dyskursywny proces wynajdowania dziedzictwa europejskiego, które legitymizuje europejski projekt polityczny ${ }^{19}$.

Jako przestrogę przed nadużyciami w tym obszarze europeizacji (top-down) traktować można uwagi poczynione przez Andrzeja Tomaszewskiego, który pisał, że

[...] pojęcie dóbr kultury - wywodzące się z zabytku - jest apolityczne i aideologiczne [...] Tymczasem, dziedzictwo kultury jest sprawą wyboru i akceptacji. Jest nim nie to wszystko, co w spadku kulturalnym zostawiły nam minione pokolenia, lecz to, co my z niego chcemy przyjąć na własność i za co chcemy wziąć odpowiedzialność. [...] Dobra kultury podlegają więc klasyfikacji według pozaestetycznych, pozanaukowych kryteriów, zazwyczaj nacjonalistyczno-szowinistycznych lub ideologiczno-klasowych. Stają się przedmiotem manipulacji i indoktrynacji politycznej, religijnej i wszelkiej innej, nagłaśnianej przez tuby propagandy ${ }^{20}$.

Innymi słowy, dziedzictwo - również to europejskie - jest wynikiem dyskursywnego procesu, któremu podlegają dobra kultury.

17 Patrz przykładowe inicjatywy: Znak Dziedzictwa Europejskiego (projekt międzyrządowy od 2005 i unijny od 2011, Europejska Stolica Kultury (decyzja o inicjatywie: 1985) oraz szlaki kulturowe Rady Europy, o których pisała Łucja Piekarska-Duraj w dysertacji doktorskiej Konstruowanie wspólnego dziedzictwa w europejskich szlakach kulturowych, obronionej na Wydziale Filozoficznym UJ w 2013 r. (manuskrypt dostępny w Bibliotece Instytutu Socjologii UJ i w Bibliotece Jagiellońskiej w Krakowie).

${ }_{18}$ Mowa tu o europejskich miejscach pamięci, a nie miejscach pamięci europejskiej. Przykładowo, patrz dyskusja Pierre'a Nory, Gesine Schwan i Roberta Traby wokół tych pojęć: Czy Europa istnieje?, „Gazeta Wyborcza”, 11 sierpnia 2007, tekst bez numeru stron dostępny na http://wyborcza.pl/1,76842,4381316.html [odczyt: 15.08.2012]. Ponadto R. Traba (red.), Pamięć. Wyzwanie dla nowoczesnej Europy, Olsztyn 2008.

${ }^{19}$ Dobrym przykładem zastosowania analizy dyskursu w badaniach nad dziedzictwem proponowanej przez Laurajane Smith (Uses of Heritage, London 2006) jest tekst: E. Narvselius, Eurovikings. European Heritage Discourses and Transnational Practices in a Viking Site [w:] The Europeanization of Heritage and Memories in..., s. 73-101. Test Narvselius stanowi próbę znalezienia w europejskim kontekście dyskursywnych procesów, o których inaczej, wcześniej i w innym kontekście pisali przykładowo: E. Hobsbawm, T. Ranger (red.), Tradycja wynaleziona, Kraków 2008, lub D. Brett, The Construction of Heritage, Cork 1996.

${ }^{20}$ A. Tomaszewski, Europa Środkowa: dobra kultury a dziedzictwo kultury [w:] J. Purchla (red.), Europa Środkowa - nowy wymiar dziedzictwa, Kraków 2002, s. 133-134. 
Opadanie europejskich idei i nawiązania do europejskich ram odniesienia poprzez implementację konkretnych odgórnych inicjatyw znamionuje tylko jeden z kierunków wpływu integracji europejskiej na współcześnie podejmowane interpretacje przeszłości i kultury. To kierunek top-down. Tymczasem podlegają mu również inicjatywy o oddolnym charakterze (bottom-up), które mogą być spontaniczne, ale również odgórnie inspirowane. Wspólną jednak ich cechą jest fakt, że nie inicjuje ich państwo, lecz społeczeństwo, szczególnie zaś lokalne i regionalne instytucje oraz aktorzy społeczeństwa obywatelskiego. I to na ich przykładzie widać, jak w lokalnym kontekście definiowana jest Europa i europejskość, jakie obrazy z wernakularnej przeszłości są z nią wiązane i jakich wartości jest Europa realizacją na tym poziomie $^{21}$. W splątaniu tendencji top-down z bottom-up daje się odczuć napięcie między politycznym celem poziomu europejskiego (uczynić Europejczyków bardziej świadomymi obywatelami UE) a ekonomicznym pragmatyzmem lokalnego zaangażowania (wykorzystać europejskie środki w celu poprawy jakości życia społeczności lokalnej). Choć - należy podkreślić - rozpiętość między idealizmem koncepcji odgórnej a pragmatyzmem inicjatyw spontanicznych jest bardzo duża i wymagałaby osobnych studiów.

Cechą oddolnych, europejskich interpretacji przeszłości jest często fakt ich wykraczania poza narodową opowieść, jej podważania i - ostatecznie nawet - zaprzeczania. O europejskości lokalnej narracji (o) przeszłości decyduje więc (jak w przypadku inicjatyw top-down) jej relacja do monolitu narodowej opowieści. Podobnie jak w przypadku odgórnej europeizacji, ta oddolna również prowadzi do kontrowania opowieści narodowej. Warto zauważyć, że model tej europeizacji często jest horyzontalny, negocjacje interpretacji przeszłości są zdecentralizowane, nierzadko (choć nie zawsze) pluralistyczne i czasami transgraniczne. W tej perspektywie wyraża się przyzwolenie na artykułowanie interpretacji lokalnych, regionalnych, transnarodowych i mniejszościowych, które odwołują się do europejskiej ramy odniesienia z pominięciem jej narodowego odpowiednika ${ }^{22}$. Państwo narodowe, choć jest obecne, to jednak jakby znika, a jego monolityczna wizja przeszłości musi walczyć z innymi interpretacjami. W konsekwencji można zgodzić się, że europeizacja lokalnego lub mniejszościowego dziedzictwa jest wyrazem słabnącej kontroli państwa nad przeszłością. I w tym zakresie budzić musi opór tych, dla których narracja narodowa jest jedyną prawdą o przeszłości. Może jednak się zdarzać, że narodowa opowieść wchłonie wernakularne interpretcje przeszłości. Wtedy jednak Europa jest - jak piszą Magdalena Góra i Barbara Törnquist-Plewa - bardziej zasobem niż celem ${ }^{23}$.

${ }^{21}$ Konkretne przykłady są omówione w: K. Kowalski, B. Törnquist-Plewa (red.), The Europeanization of Heritage and Memories in...

${ }_{22}$ Patrz np. B. Törnquist-Plewa, I. Pietraszewski,, Clashes between National and Post-national Views on Commemorating the Past: The Case of the Centennial Hall in Wrockaw [w:] B. Törnquist-Plewa, T. Andersen Sindbaek (red.), Disputed Memory, Berlin-New York 2016, s. 351-372.

${ }^{23}$ B. Törnquist-Plewa, M. Góra, The EU as a Normative Success for National Minorities. Before and After the Enlargement, „Baltic Worlds” 2014, t. VII, s. 39-50. 


\section{Polityczne konteksty i etapy europeizacji dziedzictwa}

Próby zbudowania legitymizującej relacji między dziedzictwem a dokonującym się procesem ekonomicznej i politycznej integracji w zachodniej części Europy były uwikłane w kontekst, w którym je podejmowano. Szczególnie nie były one wolne od akademickiego zaplecza, które dla procesu integracji politycznej stanowiło intelektualną bazę. Oriane Calligaro zauważyła, że zainteresowanie europejskich liderów kwestiami tożsamości, kultury i wspólnego europejskiego dziedzictwa zaczęło się w połowie lat siedemdziesiątych $\mathrm{XX}$ wieku, gdy wybuchł kryzys naftowy ${ }^{24}$. Te kwestie po raz pierwszy pojawiały się w Deklaracji Tożsamości Europejskiej podpisanej w Kopenhadze przez dziewięć państw członkowskich Europejskiej Wspólnoty Gospodarczej 14-15 grudnia 1973 roku. Ów dokument, przywołując w preambule i w jego 14 punkcie wspólne dziedzictwo europejskie oraz ponadnarodowo podzielane wartości i aspiracje ${ }^{25}$, stanowił wyraźną cezurę, po której coraz konkretniejsze stały się próby poszukiwania wspólnotowego (ponadnarodowego) wymiaru kultury, tożsamości i dziedzictwa. W ten sposób dziedzictwo europejskie stanowiło jedną z podstaw dokonującej się politycznej integracji Europy i było praktycznym nawiązaniem do fragmentu Dla Europy Roberta Schumana, który pisał, że:

Nigdy dość powtarzania, że jedności Europy nie da się stworzyć jedynie czy głównie dzięki
europejskim instytucjom; ich powstanie wypłynie ze sposobu myślenia. Nie wyrzekamy się
i nigdy nie wyrzekniemy ojczyzny, nie zapomnimy o obowiązkach wobec niej. Ale coraz wy-
raźniej rozumiemy, że ponad ojczyzną istnieje wspólne dobro, ważniejsze od interesu narodo-
wego, to wspólne dobro, na którym opierają się i w którym się spotykają indywidualne inte-
resy naszych krajów ${ }^{26}$.

Symboliczny i tożsamościowy wymiar Wspólnot zyskał na znaczeniu w latach osiemdziesiątych XX wieku. Podkreślały go: kampania „People’s Europe” Pietra Adonnino z 1985 roku, ustanowienie 9 maja Dniem Europy oraz ostateczna akceptacja w 1986 roku wspólnej europejskiej flagi i hymnu Wspólnot ${ }^{27}$. Z kolei początek lat dziewięćdziesiątych XX wieku przyniósł pierwsze próby wspólnej, europejskiej interpretacji przeszłości. C. Shore pisał o tym okresie, że europeizacji zaczęto wtedy dokonywać w edukacji, uwzględniając takie interpretacje przeszłości, które wychodziłyby poza narodowe kanony i były propozycją opowiedzenia przeszłości Starego Kontynentu z ponadnarodowej perspektywy ${ }^{28}$.

${ }^{24}$ O. Calligaro, Negotiating Europe. EU Promotion of Europeanness since the 1950s, London-New York 2013.

${ }^{25}$ Commission of the European Communities, Declaration on the European Identity, 1973, Bull EC12, C1, 2501, art. 118-127.

${ }^{26}$ R. Schuman, Dla Europy, wstęp B. Geremek, thum. M. Krzeptowska, Kraków 2003, s. XX.

27 Sh. Cris, Building Europe, London-New York 2000, szczególnie rozdział Creating the people's Europe: symbols, history and invented traditions, s. 40-65. Por. K. Kowalski, Europa: mity, modele, symbole, Kraków 2002; F. Foret, Légitimer l'Europe. Pouvoir et symbolique à l'ère de la gouvernance, Paris 2008.

${ }^{28}$ Sh. Cris, Building Europe, szczególnie podrozdział Europeanisation of mass education and the rewriting of history, s. 56-60. 
Kulminacją rehabilitacji kultury w obszarze politycznej integracji Europy było jej uwzględnienie w Traktacie z Maastricht (1992). Jego artykuł 128 w całości poświęcony był kulturze w jej narodowym i ponadnarodowym (europejskim) wymiarze. Od tego momentu Unia Europejska zaczęła podejmować więcej konkretnych inicjatyw w tym zakresie, a kultura stała się instrumentem budowania poczucia ponadnarodowej przynależności do Europy i europejskiej tożsamości. Shore pisał, że owa kulturowa legitymizacja politycznego projektu miała prowadzić do przekształcenia obywateli UE w European demos ${ }^{29}$. To dążenie - wyrażane implicytnie - znajdowało wsparcie w intelektualnym dyskursie lat osiemdziesiątych i początku lat dziewięćdziesiątych XX wieku, naznaczonym konstruktywizmem społecznym. Co więcej nawet, myślenie o Europie w owym czasie było odzwierciedleniem owego nurtu. Innymi słowy, dla Europy inspirująca stała się myśl, którą wyrażali tacy badacze, jak Benedict Anderson ${ }^{30}$, Eric Hobsbawm ${ }^{31}$ czy Ernest Gellner ${ }^{32}$ piszący, że narody i tożsamości narodowe są społecznymi konstruktami powstałymi wskutek politycznej, gospodarczej i kulturowej unifikacji. Analogia była dosyć ewidentna i prosta: skoro okazało się, że można powołać do życia wspólnoty narodowe tam, gdzie wcześniej ich nie było, to Unia Europejska - przynajmniej potencjalnie - mogłaby iść śladem jej własnych narodów. Trzeba jednak wyraźnie podkreślić, że - według Shore'a - choć praktyka działań instytucjonalnych Wspólnot w tym czasie nasuwała ową konstruktywistyczną analogię, to jednak europejscy politycy nigdy tej myśli jasno nie wyrazili, zapewne uznając, że taka analogia byłaby prowokacją wobec oponentów procesu integracyjnego.

Wyrazem konstruktywistycznego sposobu myślenia o Europie i jej przeszłości były akademickie próby skonstruowania wielkiej narracji europejskiej - czegoś na kształt European grand narrative - która dodatkowo definiowałaby to, co uchodzi (lub uchodzić powinno) za dziedzictwo europejskie. Dobrym przykładem tego rodzaju historycznego pisarstwa była Europa. Historia narodów, napisana przez Jean-Baptiste Duroselle'a ${ }^{33}$ jeszcze w latach osiemdziesiątych XX wieku z „moralnym” i do pewnego stopnia finansowanym wsparciem Komisji Europejskiej ${ }^{34}$. Jej pierwsze wydanie ukazało się w 1990 roku. Autor wyrażał w niej przekonanie o głęboko zakorzenionej kulturowej jedności Europy, wywodzącej się ze starożytnej, greckiej demokracji, rzymskiego prawa, definicji piękna utrwalonego w renesansie i z racjonalnej

29 Sh. Cris, Inventing Homo Europaeus: The Cultural Politics of European Integration, „Ethnologia Europaea. Journal of European Ethnology" 1999, vol. 29, nr 2, s. 53-66.

${ }^{30}$ B. Anderson, Imagined Communities, London 1983 (pierwsze polskie wydanie: Wspólnoty wyobrażone: rozważania o źródłach i rozprzestrzenianiu się nacjonalizmu, thum. S. Amsterdamski, Kraków-Warszawa 1997).

31 E. Hobsbawm, T. Ranger (red.), The Invention of Tradtions, Cambridge 1983 (pierwsze polskie wydanie: Tradycja wynaleziona, tłum. M. Godyń, F. Godyń, Kraków 2008).

32 E. Gellner, Nations and Nationalism, Oxford 1983 (pierwsze polskie wydanie: Narody i nacjonalizm, tłum. T. Hołówka, Warszawa 1991).

33 J.B. Duroselle, L'Europe: histoire de ses peuples, Paris 1990 (pierwsze wydanie francuskie); Europe. A History of its Peoples, London 1990 (pierwsze wydanie angielskie); Europa. Historia narodów, thum. P. Wrzosek et al., Warszawa 2002 (pierwsze wydanie polskie - 1996).

${ }^{34}$ O. Calligaro, Negotiating Europe. EU promotion of Europeanness since the 1950s, New York 2013, s. 65. 
filozofii oświecenia. Ponadto Duroselle przedstawiał Europę jako kolebkę cywilizacji i nowoczesności oraz jako obrończynię takich wartości, jak wolność, demokracja i sprawiedliwość. W owej historii narodów tkwiło założenie, że Europejczycy powinni być dumni z osiągnięć Europy i wokół nich budować ponadnarodowe poczucie przynależności i tożsamości.

Polityka promocji idyllicznego i jednoznacznie pozytywnego dziedzictwa Europy dominowała w latach osiemdziesiątych i na początku lat dziewięćdziesiątych XX wieku i można uznać ją za pierwszą falę europeizacji dziedzictwa, którą wsparły instytucje europejskie. Ten rodzaj myślenia o dziedzictwie był również obecny w pewnych przedsięwzięciach ${ }^{35}$, których najlepszym przykładem w kolejnej dekadzie - na początku XX wieku - była najpierw międzyrządowa (2005), a później unijna (2011) inicjatywa Znaku Dziedzictwa Europejskiego. Jednakże już kilka lat po podpisaniu Traktatu z Maastricht wizja europejskiej przeszłości i dziedzictwa opierających się na wielkich osiągnięciach zaczęła słabnąć. Zakwestionowano ją w obliczu przybierającej na sile krytyki płynącej z osiągnięć postmodernizmu i teorii postkolonialnej. Europejskiej grand narrative skupionej wokół osiągnięć cywilizacyjnych Starego Kontynentu postawiono zarzut europocentryzmu, ideologicznych uprzedzeń i nawet wykluczenia, jakiego dokonywała wobec tych wszystkich, których za Europejczyków nie uznawano i których dziedzictwo nie miało zostać przyjęte do europejskiego patrymonialnego kanonu.

$\mathrm{Z}$ nadejściem postmodernistycznej krytyki i teorii postkolonialnej European grand narrative padła ofiarą podejrzeń o europocentryzm i intelektualne inspiracje europejskim imperializmem, gdyż prostą konsekwencją tej wizji przeszłości i dziedzictwa Europy był wyraźny podział na Europejczyka i Innego oraz na Europę i tę resztę świata, w której ów Inny mieszka. Pęknięcie świata i napięcie między jego częściami było istotą tego właśnie rozumienia przeszłości i dziedzictwa Europy $^{36}$. Owa wizja wyrażała samozadowolenie Europy i Europejczyków, równocześnie marginalizując ciemne strony przeszłości Starego Kontynentu. Ponadto owa dychotomia prowadziła do ekskluzywnej wizji, w której uwzględniano to, co wielkie i europejskie, zapominając i/lub wybielając te fakty z przeszłości (oraz ich materialne i niematerialne pozostałości), które trudno uznać za pozytywne (np. europejski kolonializm) $)^{37}$. W obliczu poważnej krytyki obrona European grand narrative stawała się coraz trudniejsza, ostatecznie będąc nie do utrzymania.

Ponadto upadek bloku wschodniego - lata dziewięćdziesiąte XX wieku - odmienił kontekst polityczny, w którym podejmowane były próby budowania europejskiej, ponadnarodowej reprezentacji przeszłości i dziedzictwa. Znikła żelazna kurtyna. W Europie dała się odczuć potrzeba symbolicznego zjednoczenia ${ }^{38}$, i to takiego,

${ }^{35}$ Zob. decyzja o powołaniu inicjatywy Europejskiej Stolicy Kultury (1985).

${ }^{36}$ Por. S.P. Huntington, Zderzenie cywilizacji i nowy kształt ładu światowego, thum. H. Jankowska, Warszawa 2000; F. Fukuyama, Koniec historii, thum. T. Bieroń, M. Wichrowski, Poznań 1996; F. Fukuyama, Ostatni człowiek, tłum. T. Bieroń, Poznań 1997.

37 Sh. Cris, Building Europe; G. Delanty, Inventing Europe: Idea, Identity, Reality, London 1995.

${ }^{38}$ Por. A. Horolets, Obrazy Europy w polskim dyskursie publicznym, Kraków 2006; A. Horolets (red.), Europa w polskich dyskursach, Toruń 2006. 
które wykraczałoby poza narodowe imaginaria i kanony. Koniecznością okazało się scalenie Europy karolińskiej z jej wschodnią siostrą, która pozostawała poza historycznymi granicami imperium Karola Wielkiego. Co więcej, każda z tych połówek w XX wieku doświadczyła traumy i tragedii, a ich symbolami stały się Auschwitz i Gułag, które na europejskiej arenie wyraźnie zaczęły z sobą konkurować. $\mathrm{W}$ ten sposób rodziła się myśl o potrzebie wypracowania symbolicznej równowagi i konsensusu dotyczącego przeszłości, który mogłyby przyjąć społeczeństwa zachodu, środka i wschodu Europy. W konsekwencji poza dotychczasowym i jednoznacznie pozytywnym wymiarem dziedzictwa europejskiego w jego obszarze znalazła się również trudna pamięć oraz potrzeba jej przepracowania w perspektywie ponadnarodowego kompromisu i pojednania.

Przed Europą stanęło zadanie znalezienia głębokiej aksjologicznie i równocześnie nośnej społecznie wizji przeszłości, która łączyłaby narody, a nie je dzieliła i w której tkwiłaby jakaś nadzieja na przyszłość. Ta propozycja - jak się wkrótce okazało - miała uwzględnić wielość dziedzictw i ich interpretacji w Europie oraz trudne pamięci i ich przepracowanie. W nowym paradygmacie interpretacji przeszłość stawała się moralnym obowiązkiem Europejczyków, który warunkował pokojową przyszłość w ramach UE. Ponadto dziedzictwo europejskie przestało być kolekcją jednoznacznie pozytywnych faktów i obiektów wybranych z przeszłości Starego Kontynentu. Zaczęło uwzględniać w nim również negatywne wydarzenia i trudną pamięć. Takie rozumienie dziedzictwa europejskiego było konsekwencją przesunięcia akcentów z artystycznych i naukowych osiągnięć cywilizacyjnych (dziedzictwo materialne) na pamięć krzywd wzajemnie zadanych i ich przepracowanie. To była głęboka przemiana nie tylko spojrzenia na to, czym jest dziedzictwo europejskie, ale może przede wszystkim - czym jest Europa i kim są Europejczycy.

Na początku XXI wieku pozycja trudnej pamięci - zarówno tej zachodniej, jak i wschodniej, symbolizowanej przez Auschwitz i Gułag - w budowaniu wspólnej, ponadnarodowej, europejskiej reprezentacji przeszłości była w takim stopniu ugruntowana, że Claus Leggewie uznał ją za konstytutywną dla pięciu z siedmiu zaproponowanych przez siebie kręgów wspólnej, europejskiej pamięci. Były to: Holokaust, zbrodnie komunizmu, masowe wypędzenia, wszelkie wojny prowadzone w Europie oraz kolonializm. Pozostałe dwa kręgi europejskiej pamięci - by użyć jego określenia - odnosiły się, po pierwsze, do Europy jako kontynentu imigracji oraz, po drugie, do procesu politycznej integracji na Starym Kontynencie skutecznie postępującego od 1945 roku $^{39}$.

Pamięć trudna pojawiła się jednak znacznie wcześniej przed rozróżnieniem dokonanym przez Leggewiego. Otóż, Holokaust już w latach osiemdziesiątych XX wieku w USA i Izraelu zaczął ogrywać szczególną rolę w polityce pamięci ${ }^{40}$. Ponadto, jak pisała Calligaro, później - bo od lat dziewięćdziesiątych XX wieku - w Europie

${ }^{39}$ C. Leggewie, Seven circles of European Memory, ,Eurozine”, 20 grudnia 2010, http://www.eurozine.com/articles/2010-12-20-leggewie-en.html (tekst bez numracji stron) [odczyt: 1.08.2017]. Por. C. Leggewie, A.-K. Lang, Der Kampf um die europäische Erinnerung: ein Schlachtfeld wird besichtigt, München 2011.

${ }^{40}$ D. Levy, N. Sznaider, Memory Unbound. The Holocaust and the Formation of Cosmopolitan Memory, „European Journal of Social Theory” 2002, vol. 5 (1), s. 87-106. 
coraz silniej zaczęto wykorzystywać Holokaust jako mit założycielski UE ${ }^{41}$. Z pewnością o tym fakcie przesądziło wiele ówczesnych czynników, spośród których nie można przecenić rosnącej roli dyskursu skoncentrowanego na prawach człowieka w czasie wojen w byłej Jugosławii w latach dziewięćdziesiątych XX wieku i odrzucenia rasistowskiego oraz ksenofobicznego stosunku do wzmagającej fali imigrantów napływających w tym czasie do Europy. Ponadto wszelkie formy ideologii faszystowskich były dyskredytowane użyciem Holokaustu jako przykładu konsekwencji ich wprowadzenia w polityczne i społeczne życie na Starym Kontynencie.

Nie bez znaczenia był również kontekst toczących się negocjacji akcesyjnych, których ostatecznym wynikiem było wejście 10 krajów Europy Środkowej i Wschodniej do UE w 2004 roku. Z końcem lat dziewięćdziesiątych XX wieku i na początku XXI pamięć o Holokauście w oczach brukselskich elit stała się wskaźnikiem pozwalającym uchwycić, w jakim stopniu kraje kandydujące są przywiązane do wartości, na których zbudowano $\mathrm{UE}^{42}$. Były to: tolerancja, szacunek dla praw człowieka, prawa mniejszości, demokracja, rządy prawa i sprawiedliwość. Za nimi postępowało oczekiwanie wyrażane wobec wszystkich państw, a więc zarówno tych członkowskich, jak i kandydujących do UE, które dotyczyło ponownego spojrzenia na czasy Holokaustu i w konsekwencji - być może nawet przede wszystkim - krytycznej oceny ich zachowania podczas II wojny światowej (kwestia neutralności krajów, bierności jednostek wobec masowej eksterminacji Żydów etc.). Chęć dokonania głębokiej redefinicji narodowych interpretacji tego tragicznego momentu w dziejach najnowszych Europy miała diagnozować siłę i stopień, w jakim konkretne kraje podzielały europejskie wartości i skłonne były podążać bardziej europejskim niż narodowym sposobem myślenia o przeszłości, a w konsekwencji - przyszłości, która od tej pory miała być już przecież wspólna ${ }^{43}$.

W obliczu rozszerzenia na wschód, do którego doszło ostatecznie 1 maja 2004 roku, i rosnącej fali eurosceptycyzmu początek XXI wieku był dla Unii Europejskiej szczególny. Tendencje jej wzmocnienia znalazły wyraz w projekcie konstytucji UE podpisanym 29 października 2004 roku przez przedstawicieli 25 państw członkowskich rozszerzonej UE. Jednak wyrazem poglądów odwrotnych - eurosceptycznych - było odrzucenie tego dokumentu we francuskim i holenderskim referendum (2005). Tym samym na poziomie politycznej skuteczności różnorodność (diversity) wzmacniała się i zdominowała jedność (unity), a w europejskim motcie Zjednoczona w różnorodności to różnorodność zdawała się przeważać nad jednościq.

W tym kontekście próby określenia najmniejszego wspólnego mianownika, jakim dla ponadnarodowej europejskiej pamięci miał być Holokaust i II wojna światowa, nie przyniosły oczekiwanego rezultatu. Przeciwnie nawet. Otwarcie dyskusji

${ }^{41}$ O. Calligaro, Which Memories for the European Union? The Role of History and Memory in the European Integration Process [w:] E. Bussiere, E. Moradiellos (red.), Memories and Places of Memory in Europe, Bruxelles 2010, s. 47-64. Por. A. Sierp, History, Memory, and Trans-European Identity. Unifying Divisions, New York-London 2014, s. 121-132.

${ }^{42}$ Tony Judt nazwał to nawet „biletem wstępu” do UE. Zob. T. Judt, Postwar: A History of Europe Since 1945, London 2007, s. 803.

${ }^{43}$ A. Sierp, History, Memory, and Trans-European Identity... 
wokół trudnych pamięci zamiast pojednania spowodowało w Europie konflikty wokół przeszłości, przywoływanie win „drugiej strony” i rywalizację o pierwszeństwo bycia uznanym za ofiarę konkretnego konfliktu. „Intensywne pojednanie” stało się postulatem i moralnym drogowskazem na kolejne lata/dekady ${ }^{44}$.

Osłabienie i odrzucenie federacyjnych projektów dla UE (patrz: konstytucja dla Europy) znalazły odzwierciedlenie w symptomatycznym zmniejszeniu zainteresowania poszukiwaniami takiej ponadnarodowej formy pamięci i jej treści, która z założenia miała pogodzić ofiary i ich katów. Najmniejszy wspólny mianownik poszukiwany w przeszłości był do pomyślenia w zaciszu akademickich i politycznych gabinetów, jednak pamięć świadków i całych narodów stanęła na drodze jego praktycznej realizacji. Można postawić hipotezę, że w ten sposób żywa pamięć podważyła projekt instytucjonalnie inspirowanej historii ${ }^{45}$. Ten fakt stworzył możliwość, by badacze i teoretycy tłumaczący napięcie między historią a pamięcią wyszli z zacisza akademii i poza jej murami tłumaczyli realnie dziejące się procesy społeczne odnoszące się do przeszłości. I dokonywali owych analiz, tyle tylko, że często równolegle zamiast dotychczas stosowanych pojęć - np. alternatywnie do przywoływanej pamięci i historii - posługiwali się innym pojęciem, które znamionowało nadejście kolejnego paradygmatu w myśleniu o przeszłości. Było to dziedzictwo europejskie.

Nowe rozłożenie akcentów, które faworyzowało różnorodność a nie jedność, można było zauważyć w programach realizowanych przez Radę Europy i UE ${ }^{46}$. Ambicją dekady, która nastąpiła po rozszerzeniu 2004 roku, było stworzenia zarówno wspólnych ram, w których niezliczone europejskie pamięci mogłyby znaleźć przestrzeń do wysłowienia, jak i wspólnych sposobów interpretacji przeszłości oraz budowania konsensusu wokół owych interpretacji. W konsekwencji polityka pamięci na poziomie UE skupiła się na włączaniu w obręb europejskiej interpretacji wielu partykularnych perspektyw narodowych, co stało się możliwe przez odwołanie do wspólnych - bo podzielnych w UE - wartości. Były to: wolność, demokracja, tolerancja, poszanowanie praw człowieka, obywatela i mniejszości, pluralizm kultury, rządy prawa, demokracja, sprawiedliwość społeczna i pokój. Odwołanie do europejskiej aksjologii, obecnej w traktatach europejskich, umożliwiło współistnienie różnych perspektyw interpretacyjnych, nie powodując konfliktów między konkretnymi pamięciami ${ }^{47}$. Przeszłość była jedna, pamięci i historii wiele, ale to dziedzictwo miało je wszystkie pogodzić jako pozaakademicki sposób sięgania do przeszłości.

${ }^{44}$ Zob. G. Mink, L. Neumayer (red.), History, Memory and Politics in Central and Eastern Europe: Memory Games, New York 2013.

${ }^{45} \mathrm{~W}$ tym samym czasie podejmowane są pierwsze próby powołania Muzeum Europy w Brukseli i jego narracji o Europie. Zob. Ch. Véronique, L'invention du Musée de l'Europe: Contribution à l'Analyse des Politiques Symboliques Européenne, „Regards sociologiques” 2005, nr 27-28, s. 149-166.

46 Oficjalna strona programu „Europe for Citizens Programme” 2007-2013, http://ec.europa. eu/citizenship/europe-for-citizens-programme/programme-2007-2013/index_en.htm [odczyt: 29.07.2017].

${ }^{47}$ Wartości europejskie są uwzględnione w Traktacie z Lizbony. Zob. http://ec.europa.eu/ archives/lisbon_treaty/glance/rights_values/index_en.htm [odczyt: 29.07.2017]. 
Istotą nowego stosunku do przeszłości było nie tyle skupienie na własnych ofiarach lub powszechnie uznawanych osiągnięciach, ile raczej na winach i krzywdach, za które odpowiedzialność ponoszą „nasi” przodkowie. Takie ujmowanie przeszłości było głęboko zakorzenione w niemieckiej edukacji historycznej, jednak poza Niemcami wcale nie tak powszechne. Więcej nawet, budziło - i nadal zresztą budzi - poważne opory, lub nawet odrzucenie ${ }^{48}$. Przyjęcie bowiem tej perspektywy, która wychodzi poza narodowe kanony interpretacji, z natury rzeczy musi spowodować przewartościowanie spojrzenia na przeszłość. W dalszej konsekwencji prowadzi do edukacji, która ma zapobiec powtórce potworności z przeszłości ${ }^{49}$.

Krytyczne spojrzenie na własną przeszłość i uwzględnienie trudnych pamięci oraz krzywd przez ,siebie” zadanych odmieniło istotę dziedzictwa europejskiego. Ponadto w jego granicach do głosu doszły: różnorodność kultur, dialog międzykulturowy, tolerancja, (wzajemny) szacunek i uznanie. Dziedzictwo europejskie stało się przestrzenią praktycznej aplikacji filozofii dialogu, która akcent kładzie nie tylko na Ja, ale również na Ty oraz na Ty w relacji do Mnie i - ostatecznie - na Mnie w relacji do Ciebie $^{50}$. Z chwilą gdy osią dziedzictwa europejskiego stała się jednostka i jej relacje z Drugim/Innym, możliwe stało się dopuszczenie do głosu w granicach dziedzictwa zwanego europejskim grup, którym do tej pory odmawiano prawa do własnej interpretacji lub które do tej pory zupełnie marginalizowano (np. kobiety, mniejszości seksualne, mniejszości narodowe i etniczne etc.). W ten sposób dziedzictwo europejskie opuściło dobrze znany obszar pozytywnie waloryzowanej przeszłości, dla której starano się znajdować obiekty reprezentujące najwyższe wartości naukowe i artystyczne, a wyszło naprzeciw oczekiwaniom kosmopolitycznym. Dziedzictwo zaczęło zastępować narracje historyczne i pamięć.

${ }^{48}$ Zob. przykładowo: dyskusja wokół Jedwabnego: J.T. Gross, Neighbors: The Destruction of the Jewish community in Jedwabne, Oxford 2001 (polskie wydanie: Sasiedzi. Historia zagłady zydowskiego miasteczka, Sejny 2000); J.T. Gross, Fear: Anti-semitism in Poland after Auschwitz: An Essay in Historical Interpretation, Princeton-Woodstock 2006 (polskie wydanie: Strach. Antysemityzm w Polsce tuż po wojnie. Historia moralnej zapaści, Kraków 2008). Zob. również B. Törnquist-Plewa, The Jedwabne Killings - A Challenge for Polish Collective Memory [w:] U. Zander, K. Klas-Göran (red.), Echoes of the Holocaust: Historical Cultures in Contemporary Europe, Lund 2003, s. 141-176.

${ }^{49}$ J. Olick, The Politics of Regret: On Collective Memory and Historical Responsibility, London-New York 2007.

${ }^{50}$ Por. M. Buber, Ja i Ty. Wybór pism filozoficznych, Warszawa 1992; E. Levinas, Czas i to, co inne, Kraków 1999; E. Levinas, Etyka i Nieskończony. Rozmowy z Philippem Nemo, Kraków 1991; E. Levinas, Imiona własne, Warszawa 2000; J. Tischner, Filozofia dramatu, Kraków 1998; J. Tischner, Spór o istnienie człowieka, Kraków 1998. Autorzy tekstu dziękują Łucji Piekarskiej-Duraj za sugestie dotyczące powiązania filozofii dialogu z omawianymi w tym tekście kwestiami. 


\section{Podsumowanie: dziedzictwo europejskie i przyszłość}

Pojęcie dziedzictwa ma złożoną historię ${ }^{51}$. Wywodząc się z wielu pojęć, intrygująco albo uchodzi za synonim zabytku, tradycji, pamięci społecznej i miejsca pamięci, albo jest ich metaopisem i - chcę silnie podkreślić - instrumentalizacją. Z powodu swej wyjątkowej plastyczności i łatwości do wchodzenia w polityczne alianse jego sukces od lat dziewięćdziesiątych XX wieku w całej Europie (a szczególnie w Europie Środkowej) jest poniekąd zrozumiały i usprawiedliwiony. Dziedzictwo było i nadal jest bowiem - pojęciem, które 1) może obejść się bez narratywizacji przeszłości i niekoniecznie ma narodowy charakter, 2) uwzględnia trudne pamięci (a więc obejmuje również dziedzictwo niematerialne), 3) redefiniuje winę i zasługi przodków, 4) poza konstruowaniem i odczuwaniem przeszłości przez wspólnoty (np. narodowe) akcentuje również rolę jednostek w tym procesie, 5) demokratyzuje dostęp do przeszłości i jej interpretacji, 6) akcent kładzie nie tylko na prawdę historyczną, ale również na doświadczenie przeszłości, często zresztą uprzywilejowując prawdę pojedynczego odbiorcy przed prawdą akademickiej wizji przeszłości. Takiego pojęcia Europa potrzebowała na czas postępującej integracji; pojęcia, które łączyłoby tam, gdzie wszystkie inne pojęcia i sposoby budowania historycznych mostów nad trudną przeszłością zawiodły. By porównać je do innych pojęć, można powiedzieć, że wspólna europejska historia nastręczała trudności, a pamięci jednostek i wspólnot dzieliły. Tymczasem dziedzictwo było i nadal jest wielką obietnicą pojednania nad podziałami.

Dziedzictwo europejskie wraz z jego kosmopolityzmem stało się słowem kluczem, swoistą metaforą par excellence prawie „idyllicznie” przebiegającej integracji politycznej, która nastąpiła w Europie po roku 2004 roku i trwała do 2016, naznaczonego referendum w Wielkiej Brytanii, które negatywnie zweryfikowało pytanie o pozostanie tego kraju w $\mathrm{UE}^{52}$. Mając kosmopolityczny charakter, dziedzictwo jednoznacznie i pozytywnie odpowiedziało na symboliczne zapotrzebowanie odczuwane w Europie, w łonie której silniejsze były siły jednoczące niż dezintegrujące. Takim też postrzegano dziedzictwo, które dookreślano przymiotnikiem „europejskie”

51 Nie jest naszą rolą przywoływanie mocno złożonej i wielowątkowej historii pojęcia dziedzictwa. Odsyłamy czytelnika do innego tekstu na ten temat: K. Kowalski, O istocie dziedzictwa - rozważania, Kraków 2013.

${ }_{52}$ Mamy tu na myśli okres od rozszerzenia UE w 2004 roku aż do referendum w sprawie Brexitu. Por. pojęcia zbawczego kosmopolityzmu (ang. redemptive cosmopolitanism) i refleksyjnego kosmopolityzmu (ang. reflective cosmopolitanism) zaczerpnięte od Michaela Menga. Chociaż odnoszą się one do relacji niemiecko-żydowskich i polsko-żydowskich, to mogą mieć szersze zastosowanie tam, gdzie mowa o procesach zmierzających do przepracowania trudnej przeszłości w duchu demokracji i wolności. I tak, zbawczy kosmopolityzm oznacza postawę zmierzającą do oczyszczenia narodów z win popełnionych w przeszłości, często jednak bez krytycznego na nią spojrzenia. Owo stanowisko wyraża się dumnym celebrowaniem i przeżywaniem osiągniętej tolerancji oraz liberalizmu. Natomiast kosmopolityzm refleksyjny to taki, który zawiera samokrytykę, budzi gotowość do przekraczania różnic i przekształca istniejące tożsamości tak, że rodzą się nowe relacje między jednostkami i całymi wspólnotami (M. Meng, Shattered Spaces. Encountering Jewish Ruins in Postwar Germany and Poland, Cambridge, MA, 2011, s. 250). 
(choćby w jego łonie miało dochodzić do przepracowania pamięci trudnej). Za procesem integracji politycznej postępowała europeizacja przeszłości, do której znakomicie pasowało - właśnie - dziedzictwo europejskie z jego performatywnością, społeczną i polityczną sprawczością ${ }^{53}$ oraz perswazyjnością ${ }^{54}$. Jednakże nie wystarczy powiedzieć, że lustrzanym odbiciem dokonującego się procesu politycznej integracji Europy w obszarze refleksji nad przeszłością (również trudnej) było dziedzictwo europejskie. Dodać koniecznie należy, że europeizacja przeszłości dokonywała się przez samo użycie tego pojęcia do opisania znanych już faktów z przeszłości, tyle że w nowej, europejskiej, kosmopolitycznej perspektywie. Innymi słowy, dziedzictwo europejskie - po pierwsze - było i nadal jest signum temporis pewnego okresu w integracji europejskiej; po drugie jednak, europeizacja dokonywała się - i dokonuje nadal - również poprzez użycie owego pojęcia, dziedzictwa europejskiego właśnie. Rola więc dziedzictwa europejskiego jest społecznie podwójna. Po pierwsze, znamionuje ono pewien okres w historii integracji europejskiej (kładąc akcenty inaczej niż np. w narodowych narracjach). Po drugie jednak, samo jego użycie do opisu przeszłości jest narzędziem europeizowania przeszłości. O wzrastającym znaczeniu dziedzictwa w europejskim dyskursie świadczy fakt, że władze Unii Europejskiej ogłosiły rok 2018 „Europejskim Rokiem Dziedzictwa Kulturowego”.

\section{$* * *$}

Aktualna sytuacja w Europie uprawnia do stwierdzenia, że siły przeciwne integracji politycznej są coraz większym problemem dla UE. Na jednych polach konstrukcja europejska broni się (wybory parlamentarne w Holandii oraz prezydenckie i parlamentarne we Francji, 2015/2016), na innych jednak nie jest w stanie przeciwstawić się odśrodkowym, dezintegrującym procesom. Wielowymiarowy kryzys stał się faktem, czego przykładem są referendum w sprawie opuszczenia UE przez Wielka Brytanię (2016) oraz konflikty między UE i prawicowymi rządami na Węgrzech (od 2010) i w Polsce (od 2015). Nie bez znaczenia w tym kontekście jest kryzys migracyjny, kładący się cieniem na ponadnarodowych decyzjach, które do tego momentu jakoś udawało się wypracowywać. Dziś (2017) konsensus, do którego dochodziły państwa członkowskie UE, staje się problematyczny i jest coraz trudniejszy do osiągnięcia. Wyrazić można opinię, że przyczółki integracji politycznej - których jakoby nie można było utracić - w 2016 i 2017 roku padają łupem antyeuropejskich, narodowych ideologii.

To, co niedawno jeszcze było narodowym wkładem w europejskie dziedzictwo, dziś - w niektórych państwach UE - krok po kroku wraca pod panowanie monolitycznej, narodowej interpretacji. Pod wpływem kolejnej przemocy symbolicznej (wyraźnie nacjonalizującej przeszłość) kosmopolityzm słabnie jako odpowiedź

${ }^{53}$ Por. E. Domańska, Zwrot performatywny we współczesnej humanistyce, „Teksty Drugie” 2007, nr 5, s. 48-61.

${ }^{54}$ Ch.L. Stevenson, Ethics and Language, New Haven-London 1944. 
na potrzeby post(?)narodowego świata. W Europie wizja wolnej jednostki żyjącej w wielokulturowej wspólnocie przestaje odpowiadać „,nowym” politycznym narratorom. Ich „mity założycielskie” są o „nowych” bohaterach, towarzyszą ,nowym” rytuałom i stanowią część „,nowych”, wielkich narodowych celów. Te „,nowe” oczekiwania stają już przed dziedzictwem. Że im ono podoła, jest pewne, bowiem o tym, czym jest dziedzictwo, decydują sami spadkobiercy prowadzeni przez politycznych „koryfeuszy”. To oni decydują przecież, kto do wspólnoty dziedziców może należeć lub kto będzie z niej wykluczony. Nie jest to żaden „nowy” fenomen w historii Europy, ale $\mathrm{z}$ pewnością po raz pierwszy na taką skalę obserwować go można w UE. Czy ten zauważalny proces renacjonalizacji przeszłości w Europie oznacza klęskę prób budowania kosmopolitcznej pamięci? Dzisiaj (2017) tak się może wydawać, ale nic nie jest przesądzone. Procesy globalizacji i europeizacji nadal trwają i według Ulricha Becka, jednego z głównych teoretyków tych zjawisk, ich dynamika polega na ciągłej oscylacji między ,de-nacjonalizacją i renacjonalizacją, de-etnicyzacją i re-etnicyzacją, delokalizacją i re-lokalizacją"55. W 2000 roku, w długiej perspektywie oceniając procesy modernizacji, ów autor postawił diagnozę dotyczącą tego wahadłowego procesu. Jeśli w nią wierzyć, to naszym zdaniem istnieje duże prawdopodobieństwo, że po obecnym „kroku w tył” zostaną zrobione kolejne „dwa kroki w przód".

\section{Bibliografia}

Anderson B., Imagined Communities, Verso, London, 1983 (pierwsze wydanie polskie: Wspólnoty wyobrażone: rozważania o źródłach i rozprzestrzenianiu się nacjonalizmu, tłum. S. Amsterdamski, Kraków-Warszawa 1997).

Beck U., The Cosmopolitan Perspective: Sociology of the Second Age of Modernity, „British Journal of Sociology" 2000, vol. 51, issue 1 (styczeń/marzec), s. 79-105.

Börzel T., Towards Convergence in Europe? Institutional Adaptation to Europeanization in Germany and Spain, „Journal of Common Market Studies” 1999, vol. 39:4, s. 573-596.

Brett D., The Construction of Heritage, Cork 1996.

Buber M., Ja i Ty. Wybór pism filozoficznych, Warszawa 1992.

Calligaro O., Which Memories for the European Union? The Role of History and Memory in the European Integration Proces [w:] E. Bussiere, E. Moradiellos (red.), Memories and Places of Memory in Europe, Bruxelles 2010, s. 47-64.

Calligaro O., Negotiating Europe. EU promotion of Europeanness since the 1950s, New York 2013.

Charléty V., L'invention du Musée de l'Europe: Contribution à l'Analyse des Politiques Symboliques Européenne, „Regards sociologiques” 2005, nr 27-28, s. 149-166.

Convey M., Patel K.K. (red.), Europeanization in the Twenties Century. Historical Approaches, Basingstoke, Hampshire, New York 2010.

Czy Europa istnieje?, „Gazeta Wyborcza”, 11 sierpnia 2007 r., tekst bez numeru stron, http://wyborcza.pl/1,76842,4381316.html [odczyt: 15.08.2012].

Delanty G., Inventing Europe: Idea, Identity, Reality, London 1995.

${ }_{55}$ U. Beck, The Cosmopolitan Perspective: Sociology of the Second Age of Modernity, „British Journal of Sociology" 2000, vol. 51, issue 1 (styczeń/marzec), s. 98. 
Delanty G., The cosmopolitan imagination: the renewal of critical social theory, Cambridge 2009.

Delanty G., Rumford C., Rethinking Europe: social theory and the implications of Europeanization, London-New York 2005.

Domańska E., Zwrot performatywny we współczesnej humanistyce, „Teksty Drugie” 2007, nr 5, s. $48-61$.

Duroselle J.-B., L'Europe: histoire de ses peuples, Paris 1990 (pierwsze wydanie francuskie); Europe. A History of its Peoples, London 1990 (pierwsze wydanie angielskie; Europa. Historia narodów, tłum. P. Wrzosek et al., Warszawa 2002 (pierwsze wydanie polskie 1996).

Foret F., Légitimer l'Europe. Pouvoir et symbolique à l'ère de la gouvernance, Paris 2008.

Fukuyama F., Koniec historii, tłum. T. Bieroń, M. Wichrowski, Poznań 1996.

Fukuyama F., Ostatni człowiek, tłum. T. Bieroń, Poznań 1997.

Gellner E., Nations and Nationalism, Oxford 1983 (pierwsze polskie wydanie Narody i nacjonalizm, tłum. T. Hołówka, Warszawa 1991).

Graziano P., Vink M.P., Europeanization: Concept, Theory, and Methods [w:] S. Bulmer, Ch. Lesquene (red.), The Member States of the European Union, New York 2005, s. 31-54.

Gross J.T., Neighbors: The Destruction of the Jewish community in Jedwabne, Oxford 2001 (polskie wydanie: Sasiedzi. Historia zagłady żydowskiego miasteczka, Sejny 2000).

Gross J.T., Fear: Anti-semitism in Poland after Auschwitz: An Essay in Historical Interpretation, Princeton-Woodstock 2006 (polskie wydanie: Strach. Antysemityzm w Polsce tuż po wojnie. Historia moralnej zapaści, Kraków 2008).

Héritier A. et. al., Differential Europe. The European Union Impact on national Policymaking, Lanham 2001.

Hobsbawm E., Ranger T. (red.), The Invention of Tradtions, Cambridge 1983 (pierwsze wydanie polskie Tradycja wynaleziona, tłum. M. Godyń, F. Godyń, Kraków 2008).

Horolets A., Obrazy Europy w polskim dyskursie publicznym, Kraków 2006.

Horolets A. (red.), Europa w polskich dyskursach, Torun 2006.

Huntington S.P., Zderzenie cywilizacji i nowy kształt ładu światowego, thum. H. Jankowska, Warszawa 2000.

Judt T., Postwar: A History of Europe Since 1945, London 2007.

Kowalski K., Europa: mity, modele, symbole, Kraków 2002.

Kowalski K., O istocie dziedzictwa - rozważania, Kraków 2013.

Kowalski K., Törnquist-Plewa B., Heritage and Memory in a Changing Europe. Introductory Remarks [w:] K. Kowalski, B. Törnquist-Plewa (red.), Europeanization of Heritage and Memories in Poland and Sweden, Kraków 2016, s. 15-31.

Kowalski K., Törnquist-Plewa B. (red.), Europeanization of Heritage and Memories in Poland and Sweden, Kraków 2016.

Kowalski K., Euro-ethics. European Solidarity Centre in Gdańsk and the Narrative on the Polish Road to Freedom [w:] K. Kowalski, B. Törnquist-Plewa (red.), Europeanization of Heritage and Memories in Poland and Sweden, Kraków 2016, s. 103-130.

Ladrech R., Europeanization of Domestic Politics and Institutions: The Case of France, „Journal of Common Market Studies" 1994, vol. 32:1, s. 69-88.

Ladrech R., Europeanization and National Politics, Basingstoke 2010.

Leggewie C., Seven circles of European Memory, „Eurozine”, 20 grudnia 2010 r., http://www. eurozine.com/articles/2010-12-20-leggewie-en.html (tekst bez numeracji stron [odczyt: 1.08.2017]).

Leggewie C., Lang A.-K., Der Kampf um die europäische Erinnerung: ein Schlachtfeld wird besichtigt, München, 2011.

Levy D., Sznaider N., Memory Unbound. The Holocaust and the Formation of Cosmopolitan Memory, „European Journal of Social Theory” 2002, vol. 5 (1), s. 87-106.

Levinas E., Etyka i Nieskończony. Rozmowy z Philippem Nemo, Kraków 1991. 
Levinas E., Czas i to, co inne, Kraków 1999.

Levinas E., Imiona własne, Warszawa 2000.

Macdonald Sh., Difficult Heritage: negotiating the Nazi past in Nuremberg and beyond, New York 2009.

Macdonald Sh., Memorylands: heritage and identity in Europe today, London-New York 2013.

Mazurkiewicz P., Europeizacja Europy: tożsamość kulturowa Europy w kontekście procesów integracji, Warszawa 2001.

Meng M., Shattered Spaces. Encountering Jewish Ruins in Postwar Germany and Poland, Cambridge, MA, 2011.

Mink G., Neumayer L. (red.), History, Memory and Politics in Central and Eastern Europe: Memory Games, New York 2013.

Narvselius E., Eurovikings. European Heritage Discourses and Transnational Practices in a Viking Site [w:] K. Kowalski, B. Törnquist-Plewa (red.), Europeanization of Heritage and Memories in Poland and Sweden, Kraków 2016, s. 73-101.

Olick J., The Politics of Regret: On Collective Memory and Historical Responsibility, LondonNew York 2007.

Piekarska-Duraj Ł., Democratization as an Aspect of Heritage Europeanization. The Museum Triangle [w:] K. Kowalski, B. Törnquist-Plewa (red.), Europeanization of Heritage and Memories in Poland and Sweden, Kraków 2016, s. 33-57.

Piekarska-Duraj Ł., Konstruowanie wspólnego dziedzictwa w europejskich szlakach kulturowych, manuskrypt dyseracji doktorskiej obronionej na Wydziale Filozoficznym UJ (2013), dostępny w Bibliotece Instytutu Socjologii UJ i w Bibliotece Jagiellońskiej w Krakowie.

Radaelli C.M.,The Europeanization of Public Policy [w:] K. Featherstone, C.M. Radaelli (red.), The Politics of Europeanization, Oxford 2003, s. 27-56.

Risse T., Cowles M.G., J. Caporaso, Europeanization and Domestic Change: Introduction [w:] M.G. Cowles, J. Caporaso, T. Risse (red.), Transforming Europe: Europeanization and Domestic Change, Ithaca, NY, 2001, s. 1-20.

Sassatelli M., Becoming Europeans. Cultural Identity and Cultural Policies, Houndmills-Basingstoke-Hampshire 2009.

Schuman R., Dla Europy, wstęp B. Geremek, thum. M. Krzeptowska, Kraków 2003.

Shore C., Inventing Homo Europaeus: The Cultural Politics of European Integration, „Ethnologia Europaea. Journal of European Ethnology" 1999, vol. 29, nr 2, s. 53-66.

Shore C., Building Europe, London-New York 2000.

Sierp A., History, Memory, and Trans-European Identity. Unifying Divisions, New York-London 2014.

Smith L., Uses of Heritage, London 2006.

Stevenson Ch.L., Ethics and Language, New Haven-London 1944.

Tischner J., Filozofia dramatu, Kraków 1998.

Tischner J., Spór o istnienie człowieka, Kraków 1998.

Tismaneanu V., Wizje zbawienia. Demokracja, nacjonalizm i mit w postkomunistycznej Europie, Warszawa 2000.

Tomaszewski A., Europa Środkowa: dobra kultury a dziedzictwo kultury [w:] J. Purchla (red.), Europa Środkowa - nowy wymiar dziedzictwa, Kraków 2002, s. 133-134.

Törnquist-Plewa B., The Jedwabne Killings - A Challenge for Polish Collective Memory, [w:] U. Zander, K. Klas-Göran (red.), Echoes of the Holocaust: Historical Cultures in Contemporary Europe, Lund 2003, s. 141-176.

Törnquist-Plewa B., Góra M., The EU as a Normative Success for National Minorities. Before and After the Enlargement, „Baltic Worlds” 2014, tom VII, s. 39-50. 
Törnquist-Plewa B., Pietraszewski I., Clashes between National and Post-national Views on Commemorating the Past: The Case of the Centennial Hall in Wroctaw [w:] B. Törnquist-Plewa, T. Andersen Sindbaek (red.), Disputed Memory, Berlin-New York 2016, s. 351-372.

Traba R. (red.), Pamięć. Wyzwanie dla nowoczesnej Europy, Olsztyn 2008.

Werner M., Zimmermann B., Beyond Comparison: Histoire Croisée and the Challenge of Reflexivity, „History and Theory” 2006, vol. 45, nr 1 (luty), s. 30-50.

\section{Źródła internetowe:}

oficjalna strona Europejskiego Centrum Solidarności:

http://www.ecs.gda.pl/ [odczyt:1.08.2017]

oficjalna strona Muzeum II Wojny Światowej:

http://www.muzeum1939.pl/ [odczyt: 1.08.2017]

oficjalna strona programu „Europe for Citizens Programme” 2007-2013: http://ec.europa. eu/citizenship/europe-for-citizens-programme/programme-2007-2013/index_en.htm [odczyt: 29.07.2017]

omówienie wartości europejskich w Traktacie z Lizbony. Patrz: http://ec.europa.eu/archives/ lisbon_treaty/glance/rights_values/index_en.htm [odczyt: 29.07.2017]

zapis wystąpienia Prezydenta RP Andrzeja Dudy (26 maja 2017) na spotkaniu z Prezydentem Francji Emmanuelem Macron: https://www.tvn24.pl/wideo/z-anteny/sa-w-ojczyznie-rachunki-krzywd-duda-o-nowym-rozdziale-w-relacjach-polsko-francuskich, 1628411.html?playlist_ id=22892 [odczyt: 1.08 .2017 ].

\section{Oficjalne dokumenty:}

Commission of the European Communities, Declaration on the European Identity 1973, Bull EC12, C1, 2501, art. 118-127. 